\title{
Nineteenth Century Stature and Family Size: Binding Constraint or Productive Labor Force?
}

\author{
Scott Alan Carson
}

CESIFO WORKING PAPER NO. 2999

CATEGORY 4: LABOUR MARKETS

MARCH 2010

An electronic version of the paper may be downloaded

- from the SSRN website:

- from the RePEc website:

- from the CESifo website: 


\title{
Nineteenth Century Stature and Family Size: Binding Constraint or Productive Labor Force?
}

\begin{abstract}
The use of height data to measure living standards is now a well-established method in economics. Nevertheless, a neglected area in historical stature studies is the relationship between stature and family size, and statures are documented here to be positively related with family size. The relationship between material inequality and heath is the subject of considerable debate, and there was an inverse relationship between material inequality and stature. The paper also supports a bio-spatial relationship between the environment and stature.
\end{abstract}

JEL-Code: N30, D10, I10.

Keywords: family economics, stature, wealth, inequality, insolation, vitamin D.

Scott Alan Carson

University of Texas, Permian Basin

4901 East University

Odessa, TX 79762

USA

Carson_S@utpb.edu

Please do not cite without permission from the author.

I appreciate comments from Paul Hodges. 
Nineteenth Century Stature and Family Size: Binding Constraint or Productive Labor Force?

\section{Introduction}

The relationship between $19^{\text {th }}$ century stature, household size, and wealth is a neglected area in economic history, and a contributing factor in household fertility decisions was the net benefit associated with larger family sizes (Becker, 1981, p. 96). Until the $20^{\text {th }}$ century, a primary industry in the United States and European societies were associated with agriculture, and given limited physical capital and technology, $19^{\text {th }}$ century farmers typically faced a labor shortage. The net costs of having children was the present value of expected future outlays plus parental time used in the process of rearing children, less the present value of expected monetary returns plus the imputed value of childhood services (Becker, 1976, p. 175). Because in traditional societies mothers and fathers have different biological endowments and human capital, these historical benefits and costs differed from their modern counterparts (Becker, 1981, p. 22; Atack and Bateman, 1987, p. 55). As the primary care-giver, female fertility and childrearing, in turn, were related to household size and childhood health.

The use of height data to measure living standards is now a well-established method in economics (Fogel, 1994, p. 138; Deaton, 2008; Case and Paxson, 2008). A population’s average stature reflects the cumulative interaction between family size, nutrition, disease exposure, work, and the physical environment (Steckel, 1979, pp. 365-367; Tanner, 1962, pp. 1-27). By considering average versus individual stature, genetic differences are mitigated, leaving only the 
economic and physical environmental influences on stature. When diets, health, and physical environments improve, average stature increases and decreases when diets become less nutritious, disease environments deteriorate, or the physical environment places more stress on the body. Therefore, stature provides considerable insights into understanding historical processes and augments other historical welfare measures.

It is against this backdrop that this study considers the relationship between $19^{\text {th }}$ century stature and family size. Three questions are considered. First, how were $19^{\text {th }}$ century US statures associated with family size? Using a demand for children model, this paper illustrates that $19^{\text {th }}$ century statures were positively related with average household size. Second, how was stature related to average household wealth and inequality? Nineteenth century statures were positively associated with average household wealth and inversely related with wealth inequality. Third, what was the relationship between stature and occupation? After controlling for family size, wealth, and inequality, $19^{\text {th }}$ century rural farmers were taller than workers in other occupations.

\section{Fertility, Family Size, and Stature}

Fertility and household size have long fallen under the purview of labor economists and economic demographers. However, the relationship between $19^{\text {th }}$ century family size and stature is yet to be considered, and the link between household size and health outcomes is a natural extension of fertility theory. When households were small—because returns to scale were not fully exploited—additional family members increased labor specialization and increased agricultural productivity and household wealth (Becker, 1981, pp. 96-99). On the other hand, when households were large, fixed household resources may have been allocated more meagerly 
among existing family members. Therefore, there may have been either a positive or negative relationship between household size and stature.

A model is now constructed that frames household decisions to consume market related commodities and children when the number of children also influences household wealth. Assume household heads maximize utility in market related commodities, $\mathrm{X}$, and children, $\mathrm{N}$.

$$
U=U(X, N)
$$

Typical assumptions regarding first and second order conditions in $\mathrm{X}$ and $\mathrm{N}$ are maintained.

Nineteenth century household income, $y(\mathrm{~N})$, is determined by both agricultural productivity related to household size and property income, V. Household utility and income are, therefore, a function of the number of market related commodities and children. The household full income constraint is

$$
y(N)+v=\sum_{i=1}^{n} p_{i} x_{i}+\sum_{j=1}^{m} p_{N} N
$$

where $\mathrm{p}_{\mathrm{i}}$ is the price of the $\mathrm{i}^{\text {th }}$ market related commodity, and $\mathrm{p}_{\mathrm{N}}$ is the price of children. If the optimal values of market goods and children variables are assumed to be an interior solution, the first order utility maximizing conditions for utility maximization in $\mathrm{X}$ and $\mathrm{N}$ are

$$
\begin{gathered}
\frac{\partial U}{\partial X_{i}}-\lambda p_{i}=0 \\
\text { and } \\
\frac{\partial U}{\partial N}+\lambda\left(\frac{\partial y}{\partial N}-p_{N}\right)=0
\end{gathered}
$$

Corresponding shadow prices for market related commodities and children are

$$
\lambda=\frac{\frac{\partial U}{\partial X}}{p_{i}}
$$




$$
\lambda=\frac{\frac{\partial U}{\partial N}}{\left(p_{N}-\frac{\partial y}{\partial N}\right)}
$$

The shadow price for the market related commodity, (1), is straight forward and warrants no further discussion. The shadow price for children, (2), however, deserves further explanation. When the price of children, $\mathrm{p}_{\mathrm{N}}$, increases, traditional demand theory indicates the household has fewer children. However, if mid- $19^{\text {th }}$ century US agricultural mechanization was limited and when agricultural productivity related to the number of children increased, it decreased the combined price of having children and the household had more children (Becker, 1981, pp. 9699; Atack and Bateman, 1987, pp. 49-70). Household size, in turn, was related to individual family member health. Therefore, individual level stature was related with a complex set of personal demographic and occupational characteristics and state-level wealth, inequality, population density, and household size.

III. Nineteenth Century US Prison, Wealth and Demographic Data

To test the relationship between stature, wealth, inequality, population density, and family size, four data sets are constructed: $19^{\text {th }}$ century US prison data, $19^{\text {th }}$ century US statelevel average wealth and gini coefficients, a modern state-level solar radiation index, and state population densities and average family size from the 1860 and 1870 US censuses.

\section{Prison Data}

The height data used here to assess the relationship between health and observable characteristics is a subset of a much larger $19^{\text {th }}$ century prison sample. All state prison repositories were contacted and available records were acquired and entered into a master data set. These prison records include Arizona, California, Colorado, Idaho, Illinois, Kansas, Kentucky, Missouri, Ohio, Oregon, Pennsylvania, and Texas (Table 1). Between 1830 and 1920, 
prison guards routinely recorded the dates inmates were received, age, complexion, nativity, stature, pre-incarceration occupation, and crime. To take advantage of 1860 and 1870 census wealth and inequality data, the prison data used here is restricted to birth between 1855 and 1874, and only blacks and whites are considered. Inmate enumerators were quite thorough when recording inmate complexion and occupation. For example, enumerators recorded inmates’ race in a complexion category. African-Americans were recorded as black, light-black, dark-black, and various shades of mulatto (Komlos and Coclanis, 1997). Whites were recorded as light, medium, dark, fair, and white. This white race scheme is further supported by European inmates incarcerated in US prisoners, who were also recorded as light, medium, dark, fair, and white. ${ }^{1}$

Table 1, Nineteenth Century US State Penitentiaries

\begin{tabular}{l|cccc}
\hline & $\underline{1860}$ & & $\underline{1870}$ & \\
\hline & $\mathrm{N}$ & Percent & $\mathrm{N}$ & Percent \\
Arizona & & & 77 & 2.76 \\
California & 840 & 2.52 & 1,103 & 4.14 \\
Colorado & 23 & 3.60 & 71 & 4.00 \\
Idaho & & & 14 & 2.48 \\
Illinois & 1,205 & 5.02 & 100 & 5.59 \\
Kansas & 92 & 4.31 & 136 & 5.10 \\
Kentucky & 1,226 & 5.27 & 1,252 & 6.04 \\
Missouri & 1,799 & 5.09 & 2,854 & 5.75 \\
Ohio & 3,467 & 5.07 & 3,856 & 5.51 \\
Oregon & 130 & 3.66 & 108 & 5.47 \\
Pennsylvania & 2,743 & 4.99 & 2,752 & 5.43 \\
Texas & 4,655 & 5.25 & 6,566 & 6.01 \\
\hline
\end{tabular}

Source: Numbers include both white and black observations. All state prison repositories were contacted and available records were acquired and entered into a master data set. These prison

\footnotetext{
${ }^{1}$ I am currently collecting $19^{\text {th }}$ century Irish prison records. Irish prison enumerators also used light, medium, dark, fresh and sallow to describe white prisoners in prisons from a traditionally white population. To date, no inmate in an Irish prison has been recorded with a complexion consistent with African heritage.
} 
records include Arizona, California, Colorado, Idaho, Illinois, Kansas, Kentucky, Missouri, Montana, Nebraska, New Mexico, Ohio, Oregon, Pennsylvania, Texas, and Washington.

All historical data have various biases, and there is always concern over entry requirements, be it to prison or the military. Physical descriptions were recorded by prison enumerators at the time of incarceration as a means of identification. One common shortfall of military samples is a truncation bias imposed by minimum stature requirements (Fogel et al, 1978, p. 85; Sokoloff and Villaflor, 1982, pp. 459 and 472). Fortunately, prison records do not implicitly suffer from such a constraint and the subsequent truncation bias observed in military samples. However, prison records are not above scrutiny. One potential bias inherent in prison records is that they may be drawn from lower socioeconomic groups, although this bias may itself be an advantage to prison records, because lower socioeconomic groups are more vulnerable to economic change (Bogin, 1991, p. 288; Komlos and Baten, 2004, p. 199).

The shape of the stature distribution is important in stature studies because normally distributed statures allow robust estimation with standard statistical techniques. Because the youth height distribution is itself a function of the age distribution, a youth height index is constructed that standardizes for age to determine youth stature normality. First, each youth age category's average stature is calculated. Second, each observation is then divided by the average stature for the relevant age group (Komlos, 1987, p. 899). Figure 1 demonstrates there were no arbitrary stature truncation points and statures were symmetrically distributed. 
Figure 1, National Stature Histograms by Age Group
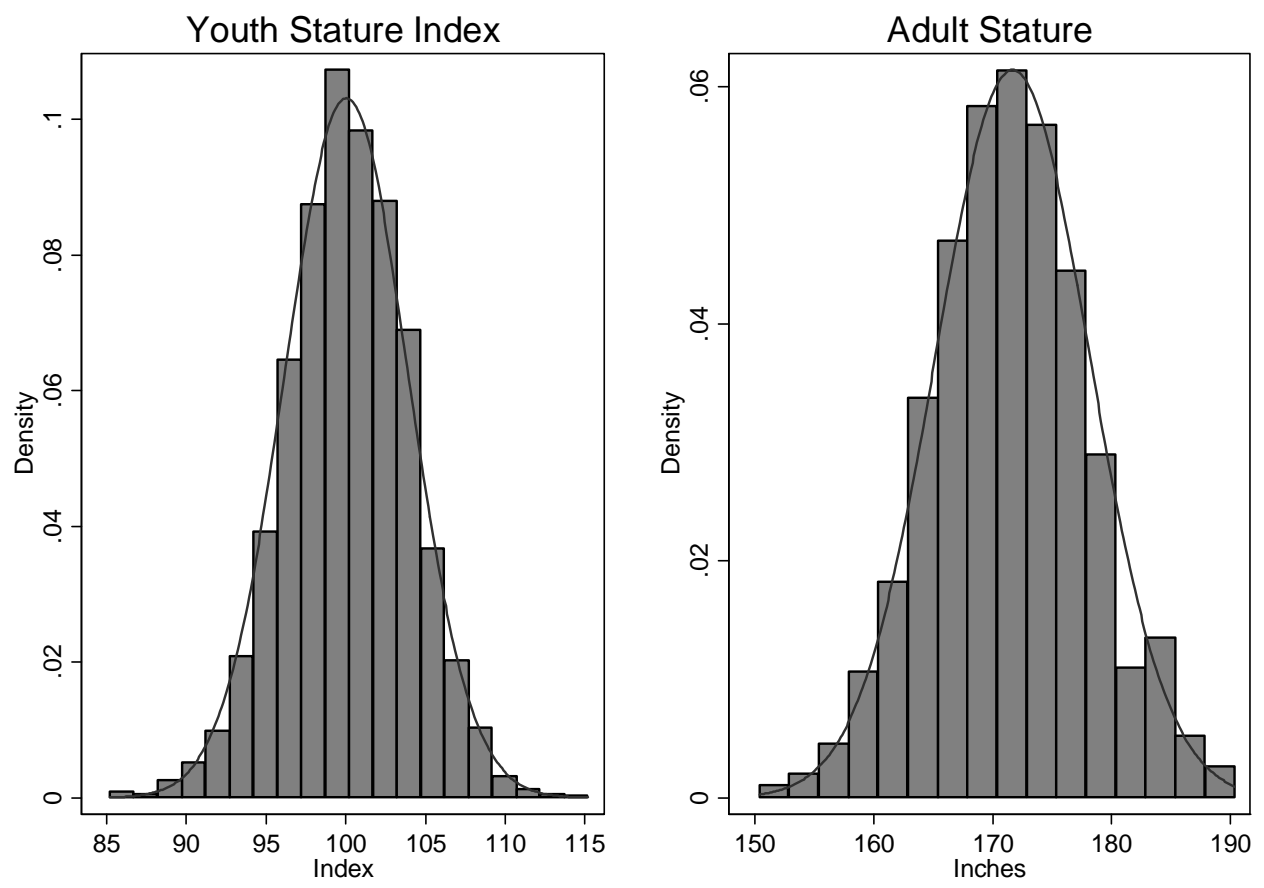

Source: see Table 1.

Occupations are a reasonable measure for socioeconomic conditions. Enumerators recorded a broad continuum of occupations and defined them narrowly, recording over 200 different occupations, which are classified here into four categories. Workers who were merchants and high skilled workers are classified as white-collar workers; light manufacturing, craft workers, and carpenters are classified as skilled workers; workers in the agricultural sector are classified as farmers; laborers and miners are classified as unskilled workers (Tanner, 1977, p. 346; Ladurie, 1979; Margo and Steckel, 1992; p. 520). Unfortunately, inmate enumerators did not distinguish between farm and common laborers. Since common laborers probably came to maturity under less favorable biological conditions, this potentially overestimates the biological 
benefits of being a common laborer and underestimates the advantages of being a farm laborer.

If there was little movement away from parental occupation, $19^{\text {th }}$ century occupations may also be a good indicator for the occupational environment in which individuals came to maturity (Costa, 1993, p. 367; Margo and Steckel, 1992, p. 520; Wannamethee et al, 1996, pp. 1256-1262; Nyström Peck and Lundberg, 1995, pp. 734-737). Because individuals are able to migrate from their birth state, only inmates incarcerated in their native state are considered here, thereby, eliminating the effects of migration on stature. By having the same prison official record characteristics over much of the period, the consistency of the prison sample creates reliable comparisons across race and time.

Table 2, Nineteen Century US Prison Inmate Demographics and Occupations

\begin{tabular}{|c|c|c|c|c|c|c|c|c|c|}
\hline $\begin{array}{l}\text { Birth } \\
\text { Decade }\end{array}$ & $N$ & $\%$ & $\bar{X}$ & S.D. & Occupation & $N$ & $\%$ & $\bar{X}$ & S.D. \\
\hline 1850 & 7,771 & 22.16 & 171.04 & 3.93 & $\begin{array}{l}\text { White- } \\
\text { Collar }\end{array}$ & 2,614 & 7.45 & 170.77 & 6.41 \\
\hline 1860 & 17,677 & 50.41 & 171.39 & 6.87 & Skilled & 5,624 & 16.04 & 170.73 & 6.49 \\
\hline 1870 & 9,621 & 27.44 & 171.12 & 6.81 & Farmer & 4,194 & 11.96 & 172.88 & 6.49 \\
\hline Race & & & & & Unskilled & 21,639 & 61.70 & 171.21 & 7.03 \\
\hline Black & 13,125 & 37.42 & 170.99 & 7.22 & $\begin{array}{l}\text { No } \\
\text { Occupation }\end{array}$ & 998 & 2.85 & 168.93 & 6.76 \\
\hline $\begin{array}{l}\text { White } \\
\text { Received }\end{array}$ & 21,944 & 62.57 & 171.38 & 6.65 & $\begin{array}{l}\text { Nativity } \\
\text { Northeast }\end{array}$ & na & na & & \\
\hline 1870 s & 3,617 & 10.31 & 169.73 & 7.28 & $\begin{array}{l}\text { Middle } \\
\text { Atlantic }\end{array}$ & 5,495 & 15.67 & 169.02 & 6.44 \\
\hline 1880s & 11,495 & 32.78 & 171.24 & 7.06 & $\begin{array}{l}\text { Great } \\
\text { Lakes }\end{array}$ & 8,628 & 24.60 & 171.60 & 6.50 \\
\hline $1890 \mathrm{~s}$ & 14,678 & 41.46 & 171.54 & 6.63 & Plains & 4,881 & 13.92 & 170.67 & 6.70 \\
\hline $1900 \mathrm{~s}$ & 5,035 & 14.38 & 171.43 & 6.69 & Southeast & 2,478 & 7.07 & 170.52 & 7.00 \\
\hline 1910s & 244 & .70 & 171.09 & 6.34 & Southwest & 11,298 & 32.22 & 172.70 & 7.11 \\
\hline
\end{tabular}

Source: See Table 1.

Table 2 presents inmate proportions and heights by decade received, race, birth decade, occupations, and nativity. More inmates were incarcerated during the 1870s than the 1860s, and 
whites were more prominent than blacks, although blacks were over represented in prisons relative to the overall population (Carson, 2008a). Occupations reflect socioeconomic status, and while prison inmates typically come from lower working classes, there were sizable inmate proportions with white-collar and skilled occupations. Many inmates were unskilled, but not abnormally so relative to the overall population. Most inmates in the prison sample were from the Southwest, with significant proportions from Great Lakes, Plains, and Middle Atlantic regions. A concern about the prison data set is that Southern prisons are over represented in the sample, and New England prisoners- one of the principal centers of industrialization and urbanization - were not available. Since Philadelphia probably accounts for a large share of the Pennsylvania sample, it may capture Northeastern industrialization; however, Philadelphia was not Boston or Providence or New York, and makes inferences from the prison data set more likely to represent the rural working class.

\section{US Average Wealth and Wealth Inequality}

The 1860 and 1870 federal censuses have been the subject of numerous $19^{\text {th }}$ century wealth studies and provide unique insight into the historical relationship between material conditions, inequality, and health as development occurred. Lee Soltow (1975) uses an 1860 and 1870 US wealth sample to demonstrate that wealth inequality did not start with industrialization and changed little between 1800 and 1940. Atack and Bateman (1981) use 1860 and 1870 census wealth to show that although wealth in the rural North was distributed more equitably than in the South, it was not a classical egalitarian society. Kearl, Pope, and Wimmer (1981) and Pope (1989) use census records to demonstrate that wealth in the Far West was distributed more equitably; however, western wealth accumulation lagged behind that of the East. 
Figure 2, 1860 and 1870 US Inequality by State

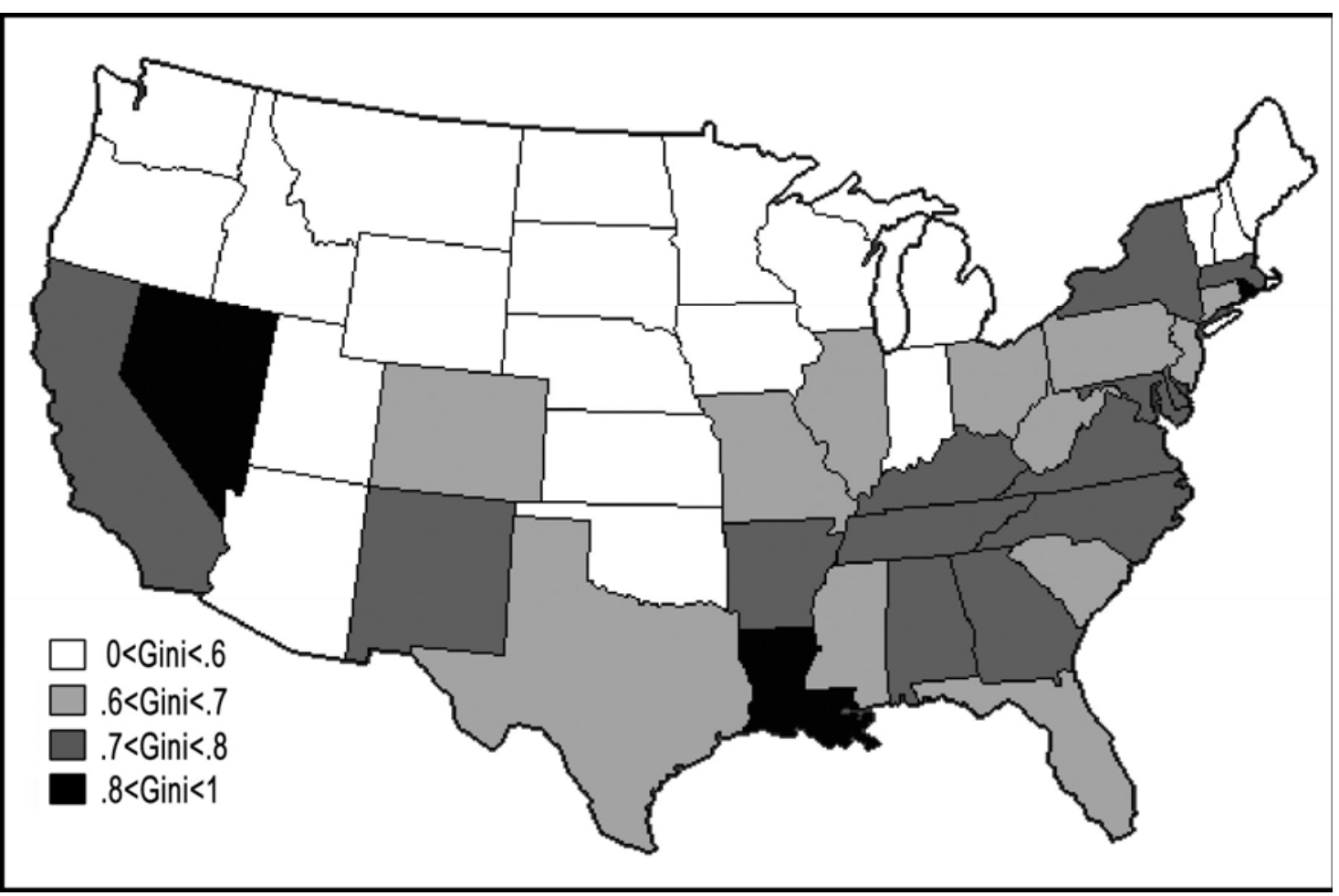

Figure 3, 1870 US Inequality by State

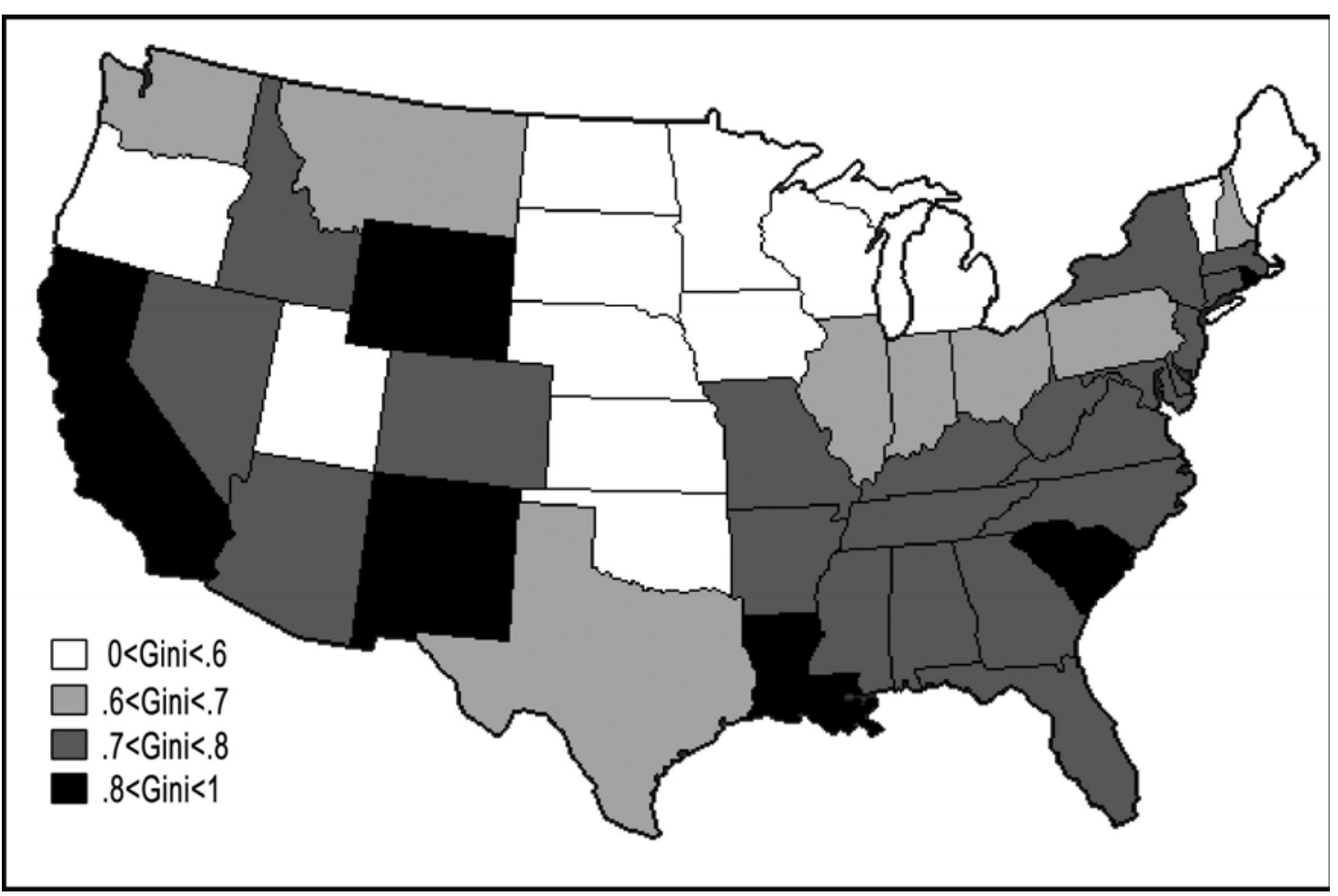


Using the Integrated Public Use Microdata Series, US wealth inequality is considered here for male headed households over the age of 18 (Figures 2 and 3). ${ }^{2}$ Eighteen sixty and 1870 total US wealth inequalities were .71606 and .71220, respectively. On the other hand, between 1860 and 1870, average total wealth decreased from \$3,289 in 1860 to \$3,018 in 1870 (Figures 4 and 5). Northern wealth holdings increased between 1860 and 1870 while maintaining relatively high wealth equality. Nevertheless, it was the North's industrialization that may have threatened Northern biological conditions. In 1860, the South had the highest average wealth and had greater wealth inequality than the North; however, with the end of slavery, average Southern wealth declined considerably while continuing to have high wealth inequality (Saltow, 1975; Easterlin, 1971). Of course, the difference was Southern chattel slavery, and once slaves were freed, southern personal wealth declined.

\footnotetext{
${ }^{2}$ No upper bound is placed on ages and all US geographic regions are considered.
} 
Figure 4, 1860 US Average State Wealth

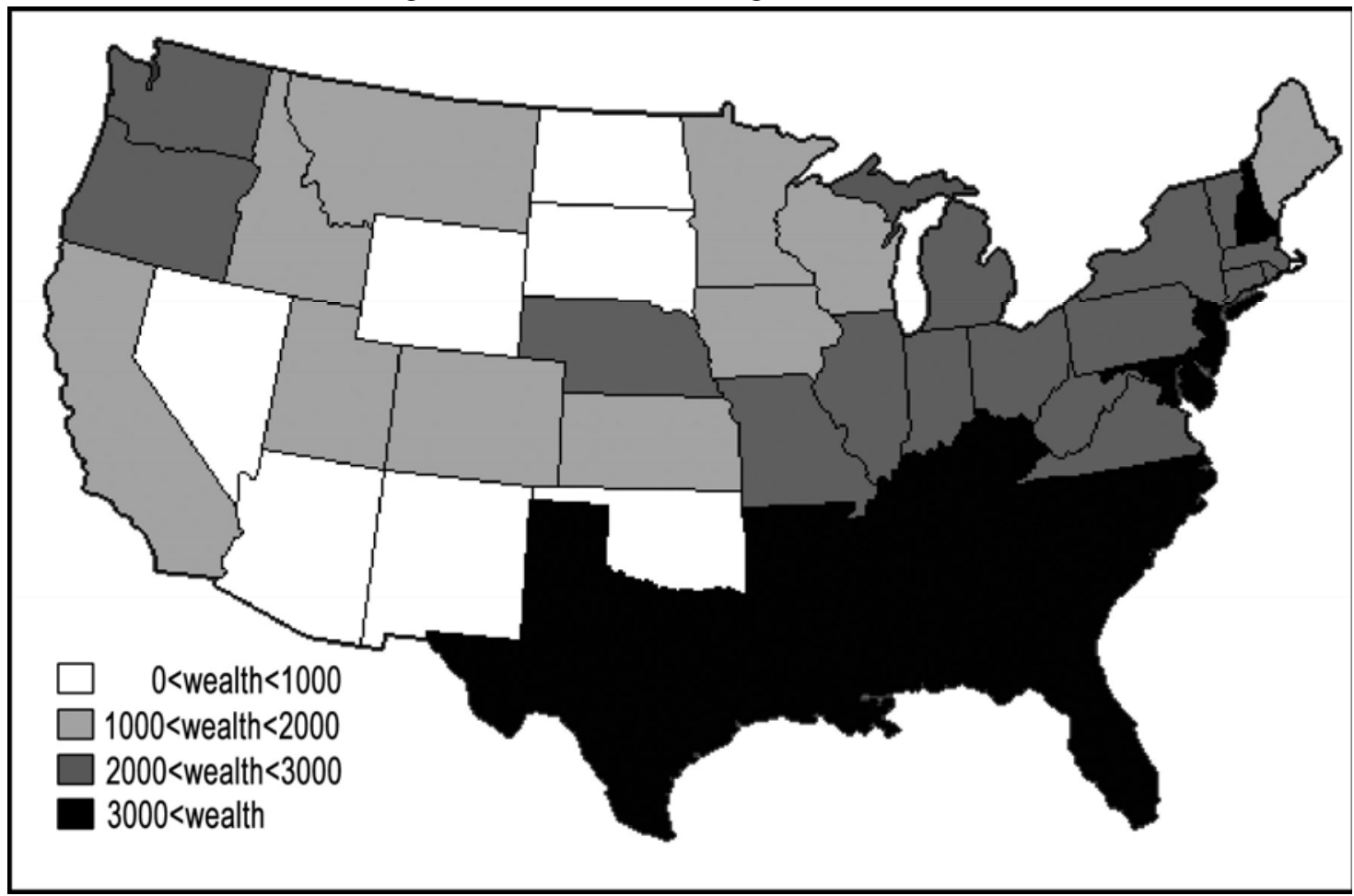

Figure 5, 1870 US Average State Wealth

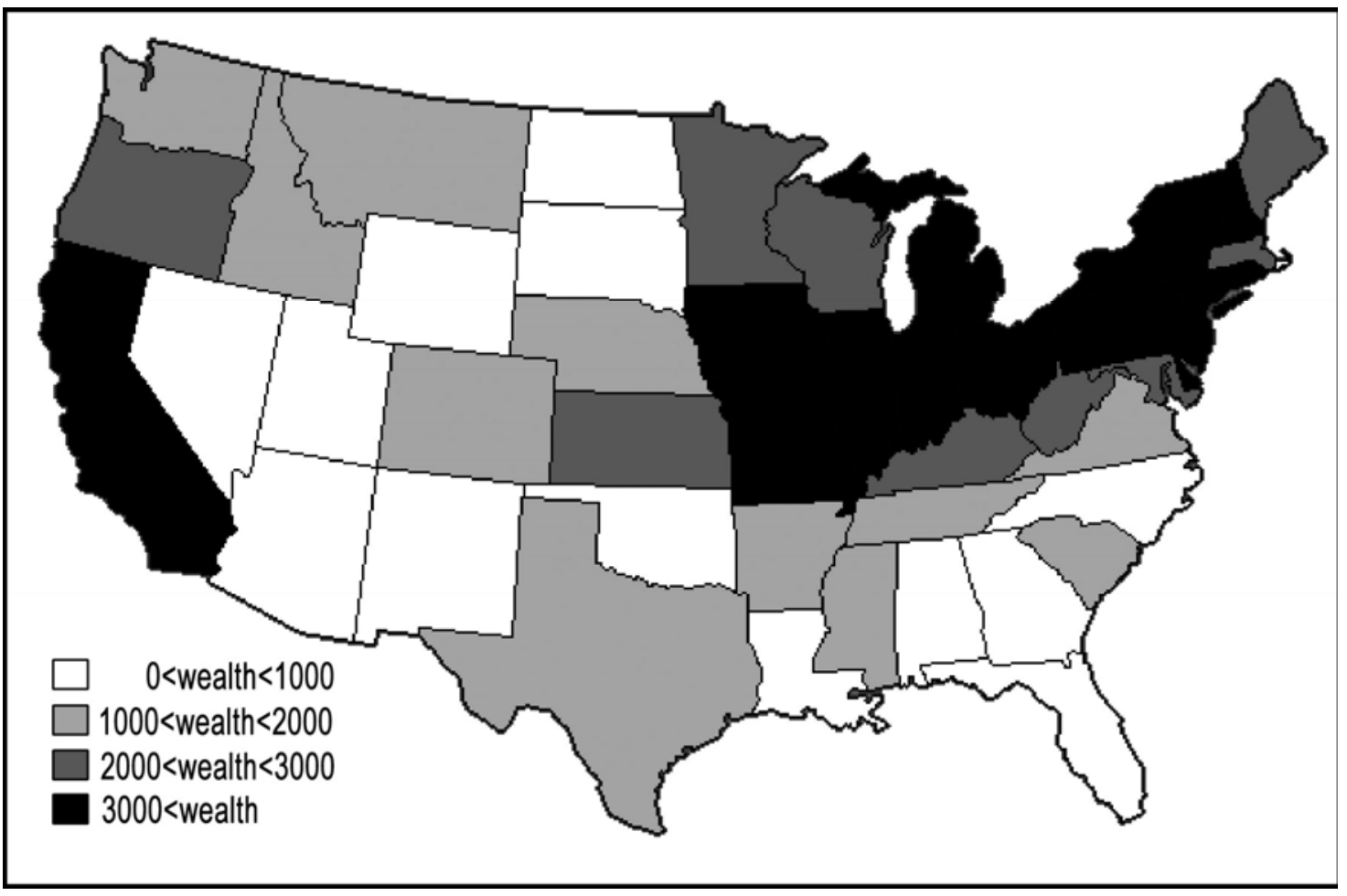




\section{Solar Radiation}

The relationship between stature and wealth is further complicated because in the middle of the $19^{\text {th }}$ century, the South had high wealth accumulation and high wealth inequality, but the South also had greater exposure to sunlight and vitamin D. All else equal, stature is positively related with wealth and may be adversely influenced by wealth inequality, both common characteristics in the antebellum South. Complicating the relationship, the South also had greater exposure to sunlight, which increases vitamin D production, and vitamin D is associated with taller statures. To account for the biological relationship between vitamin $\mathrm{D}$ and stature, a state-level insolation index is constructed. Insolation is the incoming solar radiation that reaches the earth, its atmosphere and surface objects, and it is the primary source of vitamin D (Holick, 1981, p. 590). Adult terminal statures have also been linked to vitamin D consumption (Xiong et al, 2005, pp. 228, 230-231; Liu XZ et al., 2003; Ginsburg et al., 1998; Uitterlinden, 2004), indicating that, all else equal, taller statures should be found in geographic locations that receive more insolation. In order of importance, the primary sources of vitamin D in humans are the amount of time exposed to sunlight, skin pigmentation, and nativity. (Holick, 1981, p. 590). Moreover, it is also difficult to interpret insolation's net direct effect on human health, because greater insolation reduces calories required to maintain body temperature and produces more vitamin $\mathrm{D}$, but greater insolation also warms surface temperatures, which may have made disease environments less healthy from water-borne diseases, especially in the South (Steckel, 1992, p. 501).

Because US historical insolation is unavailable, a modern insolation index (1993-2003) is constructed by weighting each state's county insolation centroid relative to the county's 
proportional square miles in the state. While this index is a rough approximation for historical insolation, it provides sufficient detail to capture state and latitudinal insolation variation and reflects vitamin D production. The US receives, on average, 4.10 hours of direct sunlight per day, and varies by proximity to the equator. Predictably, Southern states have greater insolation than Northern states, and Western states have greater insolation than Eastern states. ${ }^{3}$ For example, Wyoming and Ohio are on similar latitudes, but Wyoming receives 4.22 hours of direct sunlight per day, while Ohio receives only 3.66 hours per day. Consequently, new $19^{\text {th }}$ century American data sources introduced here make it possible to assess the various aspects of health, wealth, and inequality.

Family Size

Nineteenth century stature may have also been related to family size; therefore, a measure for state-level family size is required. Ideally individual stature is linked with individual family size. This information is, unfortunately, unavailable. However, average state family size is a reasonable proxy for individual family size, because, given local agricultural and economic

\footnotetext{
${ }^{3}$ The angle that sunlight strikes the earth's surface influences the amount of energy received at the earth’s surface, i.e., geographic locations closer to the equator receive more insolation. However, surface objects in western states received greater amounts of insolation because insolation is also influenced by elevation above sea level and cloud cover. Objects at higher elevations above sea level receive more insolation because there is less atmospheric interference from matter in the atmosphere, such as humidity. Less interference at higher elevations allows more sunlight to penetrate surface objects. The West and Southwest are also the geographic areas within North America with the least amount of cloud cover. However, the insolation index used in the regression models is the net amount of insolation after considering cloud cover because it is based upon recorded surface insolation values and not based on computer models that do not account for cloud cover.
} 
conditions, the efficient average state family size prevailed. ${ }^{4}$ Therefore, average state family size is a reasonable approximation for individual family size.

Table 3, Average Family Size by State, 1860 and 1870

\begin{tabular}{l|cccccc}
\hline & $\underline{1860}$ & & \multicolumn{5}{c}{$\underline{1870}$} \\
\hline Blacks & $\mathrm{N}$ & Average & S.D. & $\mathrm{N}$ & Average & S.D. \\
Arizona & & & & & & \\
California & & & & 14 & 1.43 & .85 \\
Colorado & & & & 3 & 1 & \\
Idaho & & & & & & \\
Illinois & 7 & 3.29 & 1.11 & 293 & 4.59 & 2.46 \\
Kansas & & & & 214 & 4.42 & 2.52 \\
Kentucky & 50 & 2.68 & 1.88 & 2,471 & 5.42 & 3.06 \\
Missouri & 4 & 4.50 & 3.51 & 1,067 & 4.82 & 2.95 \\
Ohio & 60 & 5.45 & 3.11 & 525 & 4.81 & 2.65 \\
Oregon & & & & 4 & 2.5 & 1.00 \\
Pennsylvania & 63 & 4.48 & 2.49 & 717 & 4.52 & 2.71 \\
Texas & 1 & 1 & & 2,372 & 5.78 & 2.92 \\
& & & & & & \\
Whites & 1860 & & & 1870 & & \\
Arizona & & Average & S.D. & $\mathrm{N}$ & Average & S.D. \\
California & & & & 92 & 2.76 & 1.69 \\
Colorado & & & & 4,861 & 4.38 & 2.68 \\
Idaho & & & & 369 & 4.02 & 2.42 \\
Illinois & 3,008 & 5.02 & 2.36 & 25,785 & 5.60 & 2.59 \\
Kansas & 209 & 4.31 & 2.28 & 3,509 & 5.15 & 2.73 \\
Kentucky & 4,391 & 5.45 & 2.61 & 11,086 & 6.18 & 2.74 \\
Missouri & 1,748 & 5.19 & 2.62 & 16,020 & 5.81 & 2.71 \\
Ohio & 3,967 & 5.06 & 2.35 & 25,923 & 5.52 & 2.52 \\
Oregon & & & & 887 & 5.59 & 2.82 \\
Pennsylvania & 4,888 & 5.00 & 2.35 & 33,926 & 5.45 & 2.59 \\
Texas & 706 & 5.26 & 2.70 & 5,771 & 6.10 & 7.80 \\
\hline
\end{tabular}

Source: Integrated Public Use Micro Sample, 1860 and 1870.

Using data from the 1860 and 1870 population censuses, average 1860 and 1870 household sizes are presented in Table 3. Nineteenth century white families were typically

\footnotetext{
${ }^{4}$ This explanation relies on survivorship studies that posits that if a particular plant size if it is efficient, eventually all plant sizes will adapt this technology and approach the efficient plant size (Stigler, 1958).
} 
larger than black families, and given labor scarcity on agricultural communities, both black and white family sizes increased between 1860 and 1870 . Nineteenth century family size varied considerably across the US, and the Midwest grew rapidly and had a young population, while the Northeast grew slowly and had an older population. Moreover, fertility varied by socioeconomic status, and fertility among farmers was higher than non-farmers (Atack and Bateman, 1987, p. $55)$.

IV. Individual-Level Stature, Wealth, Inequality, and Socioeconomic Status The timing and extent of stature variation not only reflects the cumulative relationship between diet and disease, but also the distribution of wealth, population density, and family size (Steckel, 1995, p. 1914). We test which of these variables were associated with $19^{\text {th }}$ century US stature.

$$
\begin{aligned}
& \text { Centimeters }_{\mathrm{ijt}}=\alpha+\sum_{\mathrm{r}=1}^{2} \beta_{\text {Race }} \text { Race }_{\mathrm{i}}+\sum_{\mathrm{A}=14}^{50 \mathrm{~s}} \beta_{\text {Age }, \mathrm{t}} \text { Age }_{\mathrm{Age}, \mathrm{t}}+\beta_{\text {Insol } \text { Insolation }_{\mathrm{j}}}+\beta_{\text {Insol }^{2}} \text { Insolation }_{\mathrm{j}}^{2} \\
& +\beta_{\mathrm{TW}} \text { Wealth }_{\mathrm{j}, \mathrm{t}}+\beta_{\mathrm{TW}^{2}} \text { Wealth }_{\mathrm{j}, \mathrm{t}}^{2}+\beta_{\text {Gini }} \text { Gini }_{\mathrm{j}, \mathrm{t}}+\beta_{\text {Wealth } \times \text { Gini }} \text { Wealth } \times \text { Gini }_{\mathrm{j}, \mathrm{t}}+\beta_{1870} 1870
\end{aligned}
$$

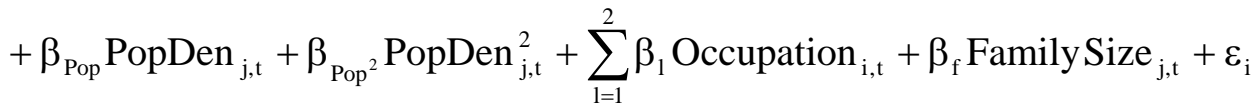

To test the relationship between stature and skin pigmentation, black and mulatto dummy variables are included. Dummy variables are added for the youth ages 14 through 19; adult age dummies are added in 10-year age categories for ages 30 through 50 age groups. To test the stature-vitamin D hypothesis, state-level continuous insolation and insolation squared terms are included. State-level continuous wealth and wealth squared variables are included to assess the relationship between stature and regional wealth levels. ${ }^{5}$ State-level gini coefficients, scaled by

\footnotetext{
${ }^{5}$ The interpretation of total wealth and state level ginis is complicated because household wealth was self-reported in the 1860 and 1870 population censuses. As much as one third of households reported holding zero total wealth,
} 
100, are included to account for 1860 and 1870 state-level wealth inequality. State-level continuous population density and population density squared terms are added to account for the effects of urbanization on stature. Occupation dummy variables are included for white-collar, skilled, farmers, and unskilled occupations. A continuous family size variable is included to test the relationship between stature and family size.

Table 4's, Model 1 presents estimates for stature regressed on age, race, insolation, wealth, inequality, population density, family size, and socioeconomic status. To illustrate how stature relates to demographic, occupation, nativity, migration, and insolation variables, models 2 through 5 omit characteristics to assess their sensitivity with stature in Model 1.

which undercounts household wealth because, at the limit, households here at least some level of trivial personal wealth. In the absence of a better estimate, it has been customary in census wealth studies to treat these households as holding zero wealth; consequently, households reporting zero total wealth are treated as holding zero wealth when calculating average wealth and state gini coefficients. 
Table 4, 1860 and 1870 US Prison Statures, Demographics, Insolation, Wealth Population Density, and Family Size

\begin{tabular}{|c|c|c|c|c|c|c|c|c|c|c|}
\hline & Model 1 & & Model 2 & & Model 3 & & Model 4 & & Model 5 & \\
\hline & Unrestricted & S.E. & $\begin{array}{l}\text { Insolation } \\
\text { Restriction }\end{array}$ & S.E. & $\begin{array}{l}\text { Wealth } \\
\text { Restriction }\end{array}$ & S.E. & $\begin{array}{c}\text { Socioeconomic } \\
\text { Status } \\
\text { Restriction }\end{array}$ & S.E. & $\begin{array}{l}\text { Population } \\
\text { Density } \\
\text { Restriction }\end{array}$ & S.E. \\
\hline $\begin{array}{l}\text { Constant } \\
\text { Race }\end{array}$ & $123.49 * * *$ & 15.35 & $185.49 * * *$ & 2.00 & $46.39 * * *$ & 11.34 & $107.44^{* * *}$ & 14.96 & $145.51^{* * *}$ & 5.11 \\
\hline White & Reference & & Reference & & Reference & & Reference & & Reference & \\
\hline Black & $-2.24 * * *$ & .105 & $-2.25^{* * *}$ & .105 & $-2.19 * * *$ & .104 & $-2.21 * * *$ & .104 & $-2.30 * * *$ & .105 \\
\hline $\begin{array}{l}\text { Mulatto } \\
\text { Ages }\end{array}$ & $-1.95 * * *$ & .124 & $-1.91^{* * *}$ & .123 & $-2.15^{* * *}$ & .124 & $-1.93 * * *$ & .124 & $-1.99 * * *$ & .124 \\
\hline 14 & $-12.17 * * *$ & .700 & $-12.15 * * *$ & 699 & $-12.38 * * *$ & .699 & $-12.23^{* * *}$ & .696 & $-12.21 * * *$ & .695 \\
\hline 15 & $-9.31 * * *$ & .479 & $-9.29 * * *$ & .480 & $-9.47 * * *$ & .479 & $-9.37 * * *$ & .482 & $-9.40 * * *$ & .481 \\
\hline 16 & $-5.16 * * *$ & .253 & $-5.12 * * *$ & .253 & $-5.20 * * *$ & .253 & $-5.14 * * *$ & .253 & $-5.23 * * *$ & .252 \\
\hline 17 & $-3.40 * * *$ & .189 & $-3.37 * * *$ & .189 & $-3.37 * * *$ & .191 & $-3.37 * * *$ & .189 & $-3.41 * * *$ & .190 \\
\hline 18 & $-2.01 * * *$ & .159 & $-2.00 * * *$ & .159 & -2.04 & .160 & $-2.01 * * *$ & .159 & $-2.04 * * *$ & .160 \\
\hline 19 & $-1.05^{* * *}$ & .147 & $-1.03 * * *$ & .147 & -1.05 & .148 & $-1.03 * * *$ & .147 & $-1.04 * * *$ & .147 \\
\hline $20 \mathrm{~s}$ & Reference & & Reference & & Reference & & & & Reference & \\
\hline $30 \mathrm{~s}$ & -.075 & .090 & -.060 & .090 & -.139 & .090 & -.129 & .090 & -.111 & .090 \\
\hline $40 \mathrm{~s}$ & $-.590 * * *$ & .169 & $-.582 * * *$ & .169 & $-.640 * * *$ & .169 & $-.641 * * *$ & .169 & $-.602 * * *$ & .169 \\
\hline $50 \mathrm{~s}$ & $-2.01^{* * *}$ & .570 & $-1.92 * * *$ & .569 & $-2.06 * * *$ & .574 & $-2.05 * * *$ & .564 & $-1.98 * * *$ & .573 \\
\hline Insolation & & & & & & & & & & \\
\hline Insolation & $28.98 * * *$ & 6.99 & & & $47.79 * * *$ & 4.90 & $33.00 * * *$ & 7.00 & $13.46^{* * *}$ & 3.00 \\
\hline $\begin{array}{l}\text { Insolation }{ }^{2} \\
\text { Wealth }\end{array}$ & $-2.91 * * *$ & .773 & & & $-4.80 * * *$ & .525 & $-3.34 * * *$ & .774 & $-1.39 * * *$ & .379 \\
\hline $\begin{array}{l}\text { Variables } \\
\text { Total Wealth }\end{array}$ & $-.005^{* * *}$ & $\frac{9.03^{-}}{8}$ & -.005 & $6.5^{-4}$ & & & $-.006 * * *$ & .001 & -.001 & $8.9^{-4}$ \\
\hline Total Wealth ${ }^{2}$ & $6.02^{-7 * * *}$ & $9.0^{-7}$ & $7.6^{-7 * * *}$ & $4.9^{-8}$ & & & $6.4^{-7 * * *}$ & $9.1^{-8}$ & $3.1^{-7 * * *}$ & $8.3^{-8}$ \\
\hline Gini coefficient & -.215 & .027 & $-.171 * * *$ & .026 & & & $-.223 * * *$ & .027 & $-.120 * * *$ & .024 \\
\hline
\end{tabular}




\begin{tabular}{|c|c|c|c|c|c|c|c|c|c|c|}
\hline $\begin{array}{l}\text { Wealth } \times \text { Gini } \\
\text { Time }\end{array}$ & $.002^{* *}$ & $<.01$ & .001 & $6.8^{-4}$ & & & $.002^{* *}$ & $8.0^{-4}$ & -.001 & .001 \\
\hline 1860 & Reference & & Reference & & Reference & & Reference & & Reference & \\
\hline $\begin{array}{l}1870 \\
\text { State }\end{array}$ & -.184 & .158 & $.497 * * *$ & .110 & $-1.72 * * *$ & .106 & -.239 & .160 & $-.263 * *$ & .108 \\
\hline Population & & & & & & & & & & \\
\hline $\begin{array}{l}\text { Population } \\
\text { density }\end{array}$ & $.166^{* * *}$ & .017 & $.094 * * *$ & .013 & $.092 * * *$ & .016 & $.175^{* * *}$ & .017 & & \\
\hline $\begin{array}{l}\text { Population } \\
\text { density }^{2} \\
\text { Socioeconomic } \\
\text { Status }\end{array}$ & $-.001^{* * *}$ & $1.4^{-4}$ & $-.001^{* * *}$ & $1.4^{-4}$ & $7.9^{-5 * * *}$ & $1.2^{-4}$ & $-.001^{* * *}$ & $\begin{array}{l}1.4 \\
4 * * *\end{array}$ & & \\
\hline $\begin{array}{l}\text { White-Collar } \\
\text { and Skilled }\end{array}$ & Reference & & Reference & & Reference & & Reference & & Reference & \\
\hline Farmer & $1.58 * * *$ & .122 & $1.61^{* * *}$ & .122 & $1.69^{* * *}$ & .122 & & & $1.63 * * *$ & .122 \\
\hline $\begin{array}{l}\text { Unskilled } \\
\text { Family Size }\end{array}$ & $.605 * * *$ & .085 & $.583^{* * *}$ & .085 & $.592^{* * *}$ & .085 & & & $.594 * * *$ & .085 \\
\hline Family Size & $.786 * * *$ & .109 & $.708^{* * *}$ & .081 & $1.68 * * *$ & .078 & $.811^{* * *}$ & .110 & $1.06 * * *$ & .102 \\
\hline $\mathrm{N}$ & 35,069 & & 35,069 & & 35,069 & & 35,069 & & 35,069 & \\
\hline $\mathrm{R}^{2}$ & .1048 & & .1032 & & .0947 & & .1000 & & .1014 & \\
\hline
\end{tabular}

Source: See Table 1. 
Three general patterns are clear when considering $19^{\text {th }}$ century US statures. First, $19^{\text {th }}$ century statures were taller when household sizes were larger, indicating that additional family members increased labor specialization and agricultural productivity (Edwards and Grossman, 1978, pp. 38-39; Atack and Bateman, 1987, p. 56). The $19^{\text {th }}$ century stature increase with family size indicates additional family members increased household wealth, offsetting increases in additional demands on household resources (Becker, 1981, pp. 97 and 102), and improved $19^{\text {th }}$ century net cumulative health and economic welfare.

Second, consistent with the biological explanation for how stature is associated with insolation, $19^{\text {th }}$ century statures increased in insolation at a decreasing rate, indicating there is a natural threshold to the amount of vitamin D produced internally, and whites in North American latitudes were closer than blacks to the threshold where vitamin D production is curtailed (Holick et al, 1981, pp. 590-591; Jablanski, 2006, p. 62; Holick, 2004a, p. 363; Holick, 2004b, p. 1680S; Carson, forthcoming). The black stature deficit may also be evidence of a previously neglected aspect of slavery's consequences on human biology: the forced migration of Africans to northern climates put blacks in biological environments wherethey were less likely to produce sufficient vitamin D and grow as tall as whites due to higher levels of melanin in their skin (Loomis, 1967, pp. 501-504; Neer, 1979, p. 441).

Third, stature relates with $19^{\text {th }}$ century wealth in at least two ways, and these mechanisms are broadly classified here into the absolute and relative wealth hypotheses. Through the absolute wealth pathway stature increases because wealth directly creates access to nutritious diets and health amenities (Steckel, 1995, p. 1914; Komlos, 1987, pp. 903; Komlos, 1998). The relative wealth-stature pathway hypothesis is that stature decreases with wealth inequality 
because relative inequality reduces access to beneficial nutrition and health inputs, which forecloses those in lower socioeconomic groups from nutrition and other health inputs (Wilkinson and Pickett, 2006, p. 1775; Subramian and Kawachi, 2004). Both absolute and relative wealth relate with $19^{\text {th }}$ century stature variation, and statures increased in absolute wealth at an increasing rate (Table 4). On the other hand, statures decreased with greater wealth inequality. The positive coefficient for the wealth-inequality interactive term also indicates that absolute wealth effects dominated the relative wealth-stature effects.

Other patterns are consistent with expectations. The degree to which white statures exceed black statures is striking, and this is significant because modern black and white statures are comparable when brought to maturity under similar biological conditions (Eveleth and Tanner, 1976; Tanner, 1977; Steckel, 1995, p. 1910; Barondess et al., 1997, p. 968; Komlos and Baur, 2004, pp. 472-473; Margo and Steckel, 1982, p. 519; Komlos and Lauderdale, 2005; Nelson, et al., 1993, pp. 18-20, Godoy et al., 2005, pp. 472-473). Moreover, compositional effects cannot explain the white-black stature differential, which was due, in part, to whites' access to meat and better nutrition (Margo and Steckel, 1992, pp. 514-515, 517, and 519).

Nineteenth century statures relate to occupations, and farmers were taller than workers in other occupations by about two centimeters (Komlos and Coclanis, 1997, p. 441; Komlos, 1987, p. 902; Steckel and Haurin, 1994, p. 170; Sokoloff and Villaflor, 1982, p. 463; Margo and Steckel, 1983, pp. 171-172; Costa, 1993, p. 367; Komlos and Coclanis, 1997; Komlos, 1987; Steckel, and Haurin, 1994; Margo and Steckel, 1982; Sokoloff and Villaflor, 1982; Carson, 2008b, pp. 822-823). Part of the explanation for taller farmers is related to nutrition, and rural farmers had greater access to nutritious diets. Another part of the farmer stature advantage may have been related to vitamin D. Islam et al. (2007, pp. 383-388) demonstrate that children 
exposed to more direct sunlight produce more vitamin D, and if there was little movement away from parental occupation, $19^{\text {th }}$ century occupations may also be a good indicator for the occupational environment in which individuals came to maturity (Costa, 1993, p. 367; Margo and Steckel, 1992, p. 520; Wannamethee et al, 1996, pp. 1256-1262; Nyström Peck and Lundberg, 1995, pp. 734-737).

\section{Discussion}

This study addresses the long-neglected relationship between $19^{\text {th }}$ century stature and household size. Individual stature increased with larger household sizes, indicating that household agricultural productivity added more to wealth than resources additional family members consumed. Statures also relate to average household wealth, and individual statures increased in average state wealth and decreased with inequality. Finally, after controlling for family size, farmers were taller than workers in other occupations. Therefore, individual stature relates with a complex set of demographic, environmental, and wealth characteristics, and the distribution of wealth within a society and within the household was related to $19^{\text {th }}$ century health. However, fertility decisions within $19^{\text {th }}$ century households implicitly increased agricultural productivity more than the costs of having children. 


\section{References}

Atack, Jeremy and Fred Batman, 1980, “The ‘Egalitarian Ideal’ and the Distribution of Wealth in the Northern Agricultural Community: a Backward Look,” Review of Economics and Statistics, March, pp. 124-129.

Atack, Jeremy and Fred Bateman, 1987, To Their Own Soil: Agriculture in the Antebellum North. Ames, Iowa: Iowa State University Press.

Barondess, D. A. Nelson, D A., \& Schlaen, S. E., (1997) "Whole Body Bone, Fat and Lean Mass in Black and White Men,” Journal of Bone and Mineral Research, 12, 967-971.

Becker, Gary. (1981). A Treatise on the Family. Harvard University Press: Cambridge.

Bogin, Barry, “Measurement of Growth Variability and Environmental Quality in Guatemalan Children,” Annals of Human Biology, 18(4), 1991, pp. 285-294.

Carson, SA (2008a) "Health During Industrialization: Evidence from the NineteenthCentury Pennsylvania State Prison System,” Social Science History 32(3), pp. 347-372. Carson, Scott Alan. (2008b) “The Effect of Geography and Vitamin D on AfricanAmerican Stature in the Nineteenth Century: Evidence from Prison Records,” Journal of Economic History. 68(3), pp. 812-831.

Carson, Scott Alan. (Forthcoming), “Nineteenth Century African-American and White US Statures: the Primary Sources of Vitamin D and their Relationship with Height,” Journal of Bioeconomics.

Case, Ann and Christina Paxson. "Height, Health, and Cognitive Function at Older Ages.” American Economic Review 98, 3 (May 2008): 463-467. 
Costa, Dora, 1993, “Height, Wealth and Disease among Native-born in the Rural, Antebellum North,” Social Science History, 17(3), pp. 355-383.

Deaton, Angus. "Height, Health, and Inequality: The Distribution of Adult Heights in India.” American Economic Review 98, 2 (May 2008): 468-474.

Easterlin, Richard. “Regional Income Trends, 1840-1950.” in The Reinterpretation of American Economic History, edited Robert Fogel and Stanley Engerman. New York: Harper \& Row. 1971. 38-53.

Edwards, Linda and Michael Grossman. (1978). “Children’s Health and the Family.” National Bureau of Economic Research.

Eveleth, Phillis B. and James M. Tanner. Worldwide Variation in Human Growth. Cambridge: Cambridge University Press. 1966. Second Ed. 1990.

Fogel, Robert W. "Economic Growth, Population Theory and Physiology: The Bearing of Long-Term Processes on the Making of Economic Policy,” American Economic Review 84(3), 1994, pp. 369-395.

Fogel, Robert, Stanley Engerman, James Trussell, Roderick Floud, Clayne Pope, and Larry Wimmer, 1978, “Economics of Mortality in North America, 1650-1910: A Description of a Research Project,” Historical Methods, 11(2), pp. 75-108.

Ginsburg, E, G. Livshits, K. Yakovenko and E. Kobyliansky, “Major Gene Control of Human Body Height, Weight and BMI in Five Ethnically Different Populations,” Annals of Human Genetics, 62, 1998, pp. 307-322.

Godoy, Ricardo E., R. Goodman, R. Levins, and W.R. Leonard. “Anthropometric Variability in the USA.” Annals of Human Biology 32, 4 (2005):469-485. Holick, Michael F, “Vitamin D: Importance in the Prevention of Cancers, Type 1 
Diabetes, Heart Disease and Osteroporosis.” American Journal of Clinical Nutrition 79. 2004a. pp. 362-371.

Holick, Michael, 2004b, “Sunlight and Vitamin D for Bone Health and Prevention of Autoimmune Diseases, Cancers, and Cardiovascular Diseases,” American Journal of Clinical Nutrition, supplement, pp. 1678S-1688S.

Holick, Michael F., A. MacLaughlin, and S. H. Doppelt. "Regulation of Cutaneous Previtamin $\mathrm{D}_{3}$ Photosynthesis in Men: Skin Pigment is not an Essential Regulator.” Science 211, 6 (February 1981): 590-593.

Islam, Talat, W. James Gauderman, Wendy Cozen, Thomas Mack, 2007, “Childhood Sun Exposure Influences Rick of Multiple Sclerosis in Monozygotic Twins,” Neurology 69, pp. 381-388.

Jablonski, Nina (2006) Skin: A Natural History. Berkeley: University of California Press. Kearl, James R., Clayne L. Pope and Larry T. Wimmer. "Household Wealth in a Settlement Economy: Utah, 1850-187." Journal of Economic History. 40(3), 1981, 477-96.

Komlos, J., 1987, The Height and Weight of West Point Cadets: Dietary Change in Antebellum America. Journal of Economic History 47, 897-927.

Komlos, John and Peter Coclanis. “On the Puzzling Cycle in the Biological Standard of Living: The Case of Antebellum Georgia.” Explorations in Economic History 34, 4 (October, 1997): 433-59.

Komlos, John. "Shrinking in a Growing Economy? The Mystery of Physical Stature during the Industrial Revolution.” This JouRnAL 58, no. 3 (1998a): 779-802. 
Komlos, John and Peter Coclanis. “On the Puzzling Cycle in the Biological Standard of Living: The Case of Antebellum Georgia.” Explorations in Economic History. 34, no. 4 (October, 1997): 433-59.

Komlos, John and Jörg Baten (2004) “Anthropometric Research and the Development of Social Science History. Social Science History. 28: 191-210.

Komlos, J., Lauderdale, B.E., 2005, Underperformance in Affluence: The Remarkable Relative Decline in the U.S. Heights in the Second Half of the $20^{\text {th }}$ Century. Social Science Quarterly 2, 283-305.

Ladurie, E. Le Roy, 1979, The Conscripts of 1968: A Study of the Correlation between Geographical Mobility, Delinquency and Physical Stature and Other Aspects of the Situation of the Young Frenchman Called to Do Military Service that Year. In: Reynolds B, Reynolds S, editors. The Territory of the Historian, (Chicago: University of Chicago Press). 33-60.

Liu, Y-Z, F-H Shen, H Deng, Y-J Liu, L-J Zhao, V Dvornyk, T Conway, J-L Li, Q-Y Huang, K M Davies, R R Recker, and H-W Deng, “Confirmation Linkage Study in Support of the X Chromosome Harbouring a ATL Underlying Human Height Variation,” Journal of Medical Genetics, 40, pp. 825-831.

Loomis, W. Farnsworth, 1967, “Skin-Pigment Regulation of Vitamin-D Biosynthesis in Man: Variation in Solar Ultraviolet at Different Latitudes may have Caused Racial Differentiation in May,” Science, pp. 501-506.

Margo Robert and Richard Steckel. "Heights of American Slaves: New Evidence on Nutrition and Health.” Social Science History 6, 4 (Fall 1982): 516-538. 
Margo, R., \& Steckel, R.H. "Heights of Native Born Northern Whites during the Antebellum Era.” Journal of Economic History 43, (1983): 167-174.

Margo, Robert and Richard Steckel. 1992, "The Nutrition and Health of Slaves and antebellum Southern whites.” in Without Consent or Contract: Conditions of Slave Life and the Transition to Freedom, edited by R. W. Fogel and S. L. Engerman, New York: Norton, 508-521.

Neer, Robert M. “The Evolutionary Significance of Vitamin D, Skin Pigment, and Ultraviolet Light,” American Journal of Physical Anthropology 43. (1979): 409-416.

Nelson, D., M. Kleerekoper, E. Peterson, \& A. M. Parfitt, “Skin Color and Body Size as Risk Factors for Osteoporosis.” Osteoporosis International, 3 (July 1993): 18-23.

Nyström-Peck, Maria and Olle Lundberg. "Short Stature as an Effect and Social Conditions in Childhood.” Social Science Medicine 41, 5 (September 1995): 733-738.

Pope, Clayne (1989) "Households on the American Frontier: the Distribution of Income and Wealth in Utah, 1850-190." Markets in History. ed. David Galenson, Cambridge University Press. 148-189.

Ruggles, Steven Matthew Sobek, Trent Alexander, Catherine A. Fitch, Ronald Goeken, Patricia Kelly Hall, Miriam King, and Chad Ronnander. Integrated Public Use Microdata Series: Version 3.0 [Machine-readable database]. Minneapolis, MN: Minnesota Population Center [producer and distributor], 2004. 
Sokoloff, K. \& Villaflor, G. (1982) “Early Achievement of Modern Stature in America,” Social Science History 6, 453-481.

Soltow, Lee, Men and Wealth in the United States, 1850-1870. 1975, New Haven: Yale University Press.

Stigler, George. (1958). “Price and non-Price Competition.” Journal of Law and Economics.

Steckel, Richard. “Slave Height Profiles from Coastwise Manifests.” Explorations in Economic History 16 (1979): 363-380.

Steckel, Richard. “ Work, Disease, and Diet in the Health and Mortality of American Slaves.” In Without Consent or Contract: Conditions of Slave Life and the Transition to Freedom, edited by Robert W. Fogel and Stanley L. Engerman, pp. 508-521. New York: Norton, 1992.

Steckel, R.H. "Stature and the Standard of Living." Journal of Economic Literature 33, (1995): 1903-1940.

Steckel, R.H. \& Haurin, D. (1994) "Health and Nutrition in the American Midwest: Evidence from the Height of Ohio National Guardsman 1850-1910.” In: Komlos, J. (Ed.), Stature, Living Standards and Economic Development. University Press of Chicago, Chicago, 117-128.

Subramanian, SV and Ichiro Kawachi. 2004. "What Have We Learned so Far?” Epidemiological Reviews 26, pp. 78-91.

Tanner, James M. Growth at Adolescence. Springfield, IL: Charles C. Thomas. 1962.

Tanner, James M, 1977, “Human Growth and Constitution,” in Harrison, GA, Weiner, JS, Tanner, JM, and Barnicot, NA (eds) Human Biology: an Introduction to Human Evolution, Variation, Growth and Ecology. pp. 301-384. 
Utterlinden, André, Yue Fang, Joyce B.J. van Meurs, Huibert A. P. Pols, Johannes P.T.M van Leeuwen, “Genetic and Biology of Vitamin D Receptor Polymorphisms,” Gene, 338, 2004, pp. 143-156.

Wannamethee, S., Peter Goya, Gerald Shaper Whincup, and Mary Walker. "Influence of Father’s Social Class on Cardiovascular Disease in Middle-Aged Men.” The Lancet 348, 9 (November 1996):1259-63.

Wilkinson, Richard G. and Kate E. Pickett, 2006, “Income Inequality and Population Health: A Review and Explanation of the Evidence,” Social Science and Medicine 62, pp. 1768-1784.

Xiong, E-H, F-H Xu, P-Y Liu, H Shen, J-R Long, L Elze, R R Recker and H-W Deng, “Vitamin D Receptor Gene Polymorphisms are Linked to and Associated with Adult Height,” Journal of Medical Genetics, 42, 2004, pp. 228-234. 


\section{CESifo Working Paper Series}

for full list see www.cesifo-group.org/wp

(address: Poschingerstr. 5, 81679 Munich, Germany, office@cesifo.de)

2933 Marco Faravelli, Oliver Kirchkamp and Helmut Rainer, Social Welfare versus Inequality Concerns in an Incomplete Contract Experiment, January 2010

2934 Mohamed El Hedi Arouri and Christophe Rault, Oil Prices and Stock Markets: What Drives what in the Gulf Corporation Council Countries?, January 2010

2935 Wolfgang Lechthaler, Christian Merkl and Dennis J. Snower, Monetary Persistence and the Labor Market: A New Perspective, January 2010

2936 Klaus Abberger and Wolfgang Nierhaus, Markov-Switching and the Ifo Business Climate: The Ifo Business Cycle Traffic Lights, January 2010

2937 Mark Armstrong and Steffen Huck, Behavioral Economics as Applied to Firms: A Primer, February 2010

2938 Guglielmo Maria Caporale and Alessandro Girardi, Price Formation on the EuroMTS Platform, February 2010

2939 Hans Gersbach, Democratic Provision of Divisible Public Goods, February 2010

2940 Adam Isen and Betsey Stevenson, Women's Education and Family Behavior: Trends in Marriage, Divorce and Fertility, February 2010

2941 Peter Debaere, Holger Görg and Horst Raff, Greasing the Wheels of International Commerce: How Services Facilitate Firms' International Sourcing, February 2010

2942 Emanuele Forlani, Competition in the Service Sector and the Performances of Manufacturing Firms: Does Liberalization Matter?, February 2010

2943 James M. Malcomson, Do Managers with Limited Liability Take More Risky Decisions? An Information Acquisition Model, February 2010

2944 Florian Englmaier and Steve Leider, Gift Exchange in the Lab - It is not (only) how much you give ..., February 2010

2945 Andrea Bassanini and Giorgio Brunello, Barriers to Entry, Deregulation and Workplace Training: A Theoretical Model with Evidence from Europe, February 2010

2946 Jan-Emmanuel De Neve, James H. Fowler and Bruno S. Frey, Genes, Economics, and Happiness, February 2010

2947 Camille Cornand and Frank Heinemann, Measuring Agents' Reaction to Private and Public Information in Games with Strategic Complementarities, February 2010 
2948 Roel Beetsma and Massimo Giuliodori, Discretionary Fiscal Policy: Review and Estimates for the EU, February 2010

2949 Agnieszka Markiewicz, Monetary Policy, Model Uncertainty and Exchange Rate Volatility, February 2010

2950 Hans Dewachter and Leonardo Iania, An Extended Macro-Finance Model with Financial Factors, February 2010

2951 Helmuth Cremer, Philippe De Donder and Pierre Pestieau, Education and Social Mobility, February 2010

2952 Zuzana Brixiová and Balázs Égert, Modeling Institutions, Start-Ups and Productivity during Transition, February 2010

2953 Roland Strausz, The Political Economy of Regulatory Risk, February 2010

2954 Sanjay Jain, Sumon Majumdar and Sharun W. Mukand, Workers without Borders? Culture, Migration and the Political Limits to Globalization, February 2010

2955 Andreas Irmen, Steady-State Growth and the Elasticity of Substitution, February 2010

2956 Bengt-Arne Wickström, The Optimal Babel - An Economic Framework for the Analysis of Dynamic Language Rights, February 2010

2957 Stefan Bauernschuster and Helmut Rainer, From Politics to the Family: How Sex-Role Attitudes Keep on Diverging in Reunified Germany, February 2010

2958 Patricia Funk and Christina Gathmann, How do Electoral Systems Affect Fiscal Policy? Evidence from State and Local Governments, 1890 to 2005, February 2010

2959 Betsey Stevenson, Beyond the Classroom: Using Title IX to Measure the Return to High School Sports, February 2010

2960 R. Quentin Grafton, Tom Kompas and Ngo Van Long, Biofuels Subsidies and the Green Paradox, February 2010

2961 Oliver Falck, Stephan Heblich, Alfred Lameli and Jens Suedekum, Dialects, Cultural Identity, and Economic Exchange, February 2010

2962 Bård Harstad, The Dynamics of Climate Agreements, February 2010

2963 Frederick van der Ploeg and Cees Withagen, Is There Really a Green Paradox?, February 2010

2964 Ingo Vogelsang, Incentive Regulation, Investments and Technological Change, February 2010

2965 Jan C. van Ours and Lenny Stoeldraijer, Age, Wage and Productivity, February 2010 
2966 Michael Hoel, Climate Change and Carbon Tax Expectations, February 2010

2967 Tommaso Nannicini and Roberto Ricciuti, Autocratic Transitions and Growth, February 2010

2968 Sebastian Brauer and Frank Westermann, A Note on the Time Series Measure of Conservatism, February 2010

2969 Wolfram F. Richter, Efficient Education Policy - A Second-Order Elasticity Rule, February 2010

2970 Tomer Blumkin, Yoram Margalioth and Efraim Sadka, Taxing Children: The Redistributive Role of Child Benefits - Revisited, February 2010

2971 Chang Woon Nam and Georg Wamser, Application of Regionally Varying Additionality Degrees in the Practice of EU Cohesion Policy, February 2010

2972 Ali Bayar, Frédéric Dramais, Cristina Mohora, Masudi Opese and Bram Smeets, Modeling Russia for Climate Change Issues, February 2010

2973 Magnus Söderberg, Informal Benchmarks as a Source of Regulatory Threat in Unregulated Utility Sectors, March 2010

2974 Piotr Wdowiński and Marta Malecka, Asymmetry in Volatility: A Comparison of Developed and Transition Stock Markets, March 2010

2975 Frans van Winden, Michal Krawczyk and Astrid Hopfensitz, Investment, Resolution of Risk, and the Role of Affect, March 2010

2976 Hyun-Ju Koh and Nadine Riedel, Do Governments Tax Agglomeration Rents?, March 2010

2977 Johann K. Brunner and Susanne Pech, Optimum Taxation of Bequests in a Model with Initial Wealth, March 2010

2978 Guglielmo Maria Caporale and Nicola Spagnolo, Stock Market Integration between three CEECs, Russia and the UK, March 2010

2979 Florian Englmaier, Ales Filipi and Ravi Singh, Incentives, Reputation and the Allocation of Authority, March 2010

2980 Konstantinos Angelopoulos, George Economides and Apostolis Philippopoulos, What is the Best Environmental Policy? Taxes, Permits and Rules under Economic and Environmental Uncertainty, March 2010

2981 Frederick van der Ploeg, Rapacious Resource Depletion, Excessive Investment and Insecure Property Rights, March 2010

2982 Wolfram F. Richter and Christoph Braun, Efficient Subsidization of Human Capital Accumulation with Overlapping Generations and Endogenous Growth, March 2010 
2983 Francesco Cinnirella, Marc Piopiunik and Joachim Winter, Why Does Height Matter for Educational Attainment? Evidence from German Pre-Teen Children, March 2010

2984 Bernard Van Praag, Well-being Inequality and Reference Groups - An Agenda for New Research, March 2010

2985 Francesca Barion, Raffaele Miniaci, Paolo M. Panteghini and Maria Laura Parisi, Profit Shifting by Debt Financing in Europe, March 2010

2986 Alexander Haupt and Magdalena Stadejek, The Choice of Environmental Policy Instruments: Energy Efficiency and Redistribution, March 2010

2987 John Komlos and Marek Brabec, The Trend of BMI Values among US Adults, March 2010

2988 Emanuele Massetti and Lea Nicita, The Optimal Climate Policy Portfolio when Knowledge Spills across Sectors, March 2010

2989 Helmut Rainer and Thomas Siedler, Family Location and Caregiving Patterns from an International Perspective, March 2010

2990 Toru Kikuchi and Ngo Van Long, A Simple Model of Service Offshoring with Time Zone Differences, March 2010

2991 Assaf Razin, Efraim Sadka and Benjarong Suwankiri, Migration and the Welfare State: Dynamic Political-Economy Theory, March 2010

2992 Bård Harstad, Buy Coal! Deposit Markets Prevent Carbon Leakage, March 2010

2993 Axel Dreher, Stephan Klasen, James Raymond Vreeland and Eric Werker, The Costs of Favoritism: Is Politically-driven Aid less Effective?, March 2010

2994 Sven Neelsen and Thomas Stratmann, Effects of Prenatal and Early Life Malnutrition: Evidence from the Greek Famine, March 2010

2995 Claude Hillinger and Bernd Süssmuth, The Quantity Theory of Money: An Assessment of its Real Linchpin Prediction, March 2010

2996 Matthew M. Chingos and Martin R. West, Do More Effective Teachers Earn More Outside of the Classroom?, March 2010

2997 Laurence Jacquet and Dirk Van de gaer, A Comparison of Optimal Tax Policies when Compensation or Responsibility Matter, March 2010

2998 Valentina Bosetti, Carlo Carraro, Romain Duval and Massimo Tavoni, What Should we Expect from Innovation? A Model-Based Assessment of the Environmental and Mitigation Cost Implications of Climate-Related R\&D, March 2010

2999 Scott Alan Carson, Nineteenth Century Stature and Family Size: Binding Constraint or Productive Labor Force?, March 2010 